\title{
Some Chemical Aspects on Anthocyanin Coloration Caused by $C$ and $S p$ Allelomorphic Series of Genes
}

\author{
Genetical Studies on Rice Plant XX*
}

by Seijin Nagao, ${ }^{* *}$ Man-emon TaKahashi** and Takao Mryamoto**

\author{
長尾正人**・高橋万右衛門**・㗬本隆夫**：C 系及び $S p$ 系複対立遺伝子に関する \\ 花青素着色の化学的性状 (稲の交雑に関する研究 $\mathrm{XX}^{*}$ )
}

Received April 30, 1956

\section{Introduction}

In the past, it has been assumed that the expression of various hues and shades of anthocyanin coloration in rice plant necessitates the existence of a modifier which controls the color intensity in addition to the chromogen and its modifier, which in turn converts chromogenic substance to anthocyanin (Nagai 1921, Yamaguchi 1926, Chao 1928, Jones 1930 etc.).

However, the authors have not yet arrived at the occasion where any other intensifying modifier is required, so far as our cross experiments are concerned (Nagao and Takahashi 1947, 1951). A detailed account on this interpretation, being tedious, is abridged here, and is summarized as follows.

According to the authors' genic scheme, anthocyanin coloration depends on the complementary effect of gene $C$ and $S p$. The $C$ is responsible for the formation

oi $\mathrm{chr}$ omogen, and the gene $S p$ exerts its modifying effect on $C$ and turns the chromogen to anthocyanin. Five alleles, $C^{B}>C^{B p}>C^{B t}>C^{B r}>C^{+}$, have been discovered at the $C$ locus and three, $S p>S p^{d}>S p^{+}$, at the $S p$ locus. Therefore, the expression of anthocyanin color character can be said to be determined by the combination of alleles of the $C$ and $S p$ loci. The following is the relation of hue and shade arranged according to color intensity in the ascending order.

violet. red. pink. colorless

$C^{B} S p>C^{B p} S p>C^{B} S p^{d}>C^{B p} S p^{d}>C^{B t} S p>C^{B r} S p>S^{B t} S p^{d}>C^{B r} S p^{d}>S p^{+}$

Coloration occurs primarily in the glume apex, namely the apiculus, as a result of the interaction of the said two kinds of genes; and thereupon if the gene $R p$, $P l$ or $P n$, which are regarded as the distributing modifier for anthocyanin coloration, coexist with $C$ and $S p$; the glume, the leaf or the node are also colored with anthocyanin respectively.

* Contribution from the Plant Breeding Institute, Faculty of Agriculture, Hokkaido University.

** Plant Breeding Institute, Faculty of Agriculture, Hokkaido University, Sapporo, Japan. 北海道大学農学部育種学教室 
To take an objective view of genic interpretation on these colorations, it is necessary to investigate not merely an account of the genic analysis of their characteristics by means of hybridization experiments, but also consideration of the biochemical analysis of the said characteristics. In the present paper the authors intend to deal with some chemical natures on anthocyanin coloration due to the presence of $C, S p$ and their modifiers $R p, P l$ and $P n$.

Before going further, the authors wish to express their gratitude to Prof.Y.Nakamura, who has tendered many suggestions from his speciality, and Dr. K. Hayashi for the use of an authentic specimen which was exceedingly valuable in identification of the anthocyanin concerned. Expense of this work was partly defrayed from a grant for Fundamental Scientific Research of Ministry of Education.

\section{Materials}

The details are given in the sections of experimental results, but in general the investigation was accomplished using strains which have been bred true for coloration with regard to the $C$ and $S p$ series of multiple allelomorphic genes and their distributing modifiers, and in a few cases some genotypic individuals derived from one $\mathrm{F}_{2}$ population were used.

\section{Experimental Results}

I. In order to determine whether various color intensities, $i$. $e$. blackish purple to rose pink, are caused by identical anthocyanins or not, several genotypes in connection with $C$ and $S p$ alleles were examined by means of paper chromatographic method.

The glume apices and their awns were taken and collected two to three days after flowering, and the anthocyanins contained in above parts were extracted with $1 \%$ solution of hydrochloric acid. The extracted solutions were spotted on filter papers (No. 50 of Toyo Roshi Co., Ltd.) and dried at $26^{\circ}$ C. Separation of anthocyanins was conducted by the use of a mixture of $n$-butanol, glacial acetic acid and distilled water in a ratio of $4: 1: 2$, as advocated by Bate-Smith (1948). After one dimensional separation of the extracts, the filter papers were dried at room temperature, and $\mathrm{Rf}$ values of anthocyanins were observed and calculated. The results are as shown in Table 1.

In this table it is pointed out that almost all genotypes show similar values of Rf, ranging from 0.41 to 0.43 .

The same Rf values were obtained in the extracts from another colored parts in which the localization of color depended on the presence of distributing genes $R p$, $P l$ and $P n$, under the coexistence of fundamental apiculus genes $C$ and $S p$. This result is given in Table 2 . 
Table 1. Rf values of anthocyanins extracted from apiculus and awns of different genotypic individuals or strains (some combinations of alleles of the $C$ and $S p$ loci).

\begin{tabular}{|c|c|c|c|c|}
\hline Genotype & $\begin{array}{c}\text { Hue and shade } \\
\text { of } \\
\text { color } 1)\end{array}$ & $\begin{array}{c}\text { Strain or } \\
\text { population no. }\end{array}$ & $\begin{array}{l}\text { Part selected } \\
\text { for } \\
\text { examination }\end{array}$ & $\begin{array}{c}\text { Rf } \\
\text { value }\end{array}$ \\
\hline \multirow{2}{*}{$C^{B} S p$} & \multirow{2}{*}{ Blackish purple } & $A-2$ & apiculus and awns & 0.42 \\
\hline & & $A-58$ & " & "l \\
\hline \multirow{2}{*}{$C B p S p$} & \multirow{2}{*}{ Pansy purple } & $A-107$ & "l & 0.41 \\
\hline & & A-77 & apiculus & 0.43 \\
\hline$C B S p^{d}$ & Aster purple & $A-18$ & " & 0.42 \\
\hline$C B p S p^{d}$ & Amaranth purple & A-83 & " & "l \\
\hline$C B r S p$ & Rose red & $A-5$ & apiculus and awns & "l \\
\hline
\end{tabular}

1) Refer to Ridgway's Color Standards.

Table 2. Rf values of anthocyanins extracted from organs other than apiculus and awns.

\begin{tabular}{|c|c|c|c|c|c|}
\hline $\begin{array}{l}\text { Distri- } \\
\text { buting } \\
\text { modifier }\end{array}$ & $\begin{array}{l}\text { Mode of color } \\
\text { distribution } \\
\text { by modifier }\end{array}$ & $\begin{array}{l}\text { Basic } \\
\text { genotype }\end{array}$ & $\begin{array}{c}\text { Strain or } \\
\text { population } \\
\text { no. }\end{array}$ & $\begin{array}{l}\text { Part selected } \\
\text { for } \\
\text { examination }\end{array}$ & $\begin{array}{c}\mathrm{Rf} \\
\text { value }\end{array}$ \\
\hline \multirow{2}{*}{$R p$} & \multirow{2}{*}{$\begin{array}{l}\text { Entire glume } \\
\text { and } \\
\text { rachilla }\end{array}$} & $C^{B} S p$ & A-58 & glume & 0.42 \\
\hline & & $C B D S p$ & A-107 & " & 0.43 \\
\hline \multirow{7}{*}{$P l$} & \multirow{7}{*}{$\begin{array}{l}\text { Entire leaf blade and } \\
\text { sheath, ligule, pulvinus, } \\
\text { auricle, stem and node }\end{array}$} & $C^{B} S p$ & D-25 & leaf blade & 0.42 \\
\hline & & \multirow{5}{*}{$C R P S p$} & \multirow{3}{*}{ A-77 } & " & $\prime \prime$ \\
\hline & & & & leaf sheath & $" \prime$ \\
\hline & & & & node & 0.43 \\
\hline & & & $A-38$ & leaf blade & 0.42 \\
\hline & & & $\mathrm{N}-45$ & $\prime \prime$ & "I \\
\hline & & $C B S p d$ & $\mathrm{~N}-4$ & " & " \\
\hline \multirow{6}{*}{$P n$} & \multirow{6}{*}{$\begin{array}{l}\text { Leaf margin, leaf sheath, } \\
\text { pulvinus, auricle and } \\
\text { node }\end{array}$} & \multirow{6}{*}{$C B S p$} & A- 65 & leaf margin & 0.41 \\
\hline & & & \multirow{3}{*}{ A-2 } & " & 0.42 \\
\hline & & & & ligule & " \\
\hline & & & & node & 0.41 \\
\hline & & & \multirow{2}{*}{$A-58$} & leaf margin & " \\
\hline & & & & node & 0.42 \\
\hline
\end{tabular}


These two results lead the authors to the conclusion that there is no differences among the several genotypes in regards to the quality of anthocyanin concerned.

II. Further, to clarify an aglucone of this anthocyanin, the colored leaf blade with the genic constitution of $C^{B} S p P l$ was collected at a time slightly before panicle emergence and was ground into flinders. Extracted solutions of $1 \%$ hydrochloric acid were taken from the flinders and were treated according to the qualitative analysis of aglucone offered by Robinson and Robinson (1931). The water solution of aglucone, the resulting hydrolysed substance, shows the following results of examination.

i) The sample shows a violet color when sodium acetate is added to its amyl alcohol extract and ferric chloride changes the said violet to dark blue.

ii) The sample is fairly stable in a solution of $10 \%$ sodium hydroxide.

iii) A small portion of aglucone is extracted when the solution is shaken with an equal volume of a mixture of cyclohexanol ( 1 vol.) and toluene ( 5 vols.).

iv) And it is also extracted, to a certain extent, in a $5 \%$ solution with an equal volume of amyl ethyl ether ( 1 vol.) and anisol (4 vols.).

Identical results are obtained from materials from genotype $C^{B p} S p P l$, using the same methods.

Therefore, these results seem to indicate that the anthocyanin, which is present in rice plant, and which depends on the multiple allelomorphic series of gene, $C$ and $S p$, has cyanidin as its aglucone.

III. For verification of this assumption, the aglucone of anthocyanins extracted from the genotypes of $C^{B} S p P l$ and $C^{B D} S p P l$ were paper-chromatographically identified, and compared with cyanidin specimen, by means of Hayashi and Abe's method (1952). A mixture of iso-amyl alcohol, $36 \%$ hydrochloric acid and distilled water in a ratio of $5: 1: 1$, and Toyo No. 50 filter paper were used for this purpose with the temperature at $25^{\circ} \mathrm{C}$.

According to this one dimensional paper chromatography the Rf values of all samples invariably show the same values of $0.63-0.64$, which are equal to that of the cyanidin specimen; $\mathrm{Rf}=0.63$.

\section{Considerations}

It has been reported that at least one of the aglucones involved in rice anthocyanin is identified as cyanidin by Hayashi (1944). However this study was carried out from chemical point of view, by using purple leaf blades of only one type of coloration in so-called "Murasaki-ine". It is unfortunate that the genic constitution of Hayashi's sample is not ascertained.

The authors have made previous studies on anthocyanins in various parts of rice of several genotypes or genic constitutions with regard to the $C$-chromogen, $S p$-modifier and their distributing genes $R p, P l$ and $P n$, and determined that these 
anthocyanins were the same, with no qualitative differences in spite of numerous variations in color, hue and shade or localization of colors.

And it is emphasized that the aglucone of this anthocyanin was identified to be cyanidin, without exception.

On the whole, therefore, the authors have arrived at the conclusion that the differences of the affection of allelomorphic genes $C^{B}, C^{B p}, C^{B t}, C^{B r}$ anb $C^{+}$are to be regarded as quantitative, and the same should be considered to hold in the case of $S p, S p^{d}$ and $S p^{+}$, though more detailed analysis extending over all genotype combinations would be necessary to determine this opinion conclusively.

\section{Summary}

1. The anthocyanin pigments contained in rice plants were analysed by means of paper chromatography, and it was revealed that the said anthocyanins were the same with no qualitative differences within the combinations of color genes, and hues and shades of colors as specified above.

2. The aglucone of this anthocyanin was identified as cyanidin.

\section{Literature}

Bate-Smite, E. C., Nature 161: 835-838 (1948). Chao, L. F., Genetics 13: 133-169 (1928). Hayashi, K., Acta Phytochim. 14: 70 (1944). - Misc. Rep. Res. Inst. Nat. Resources 18 : $1-8$ (1946). and Abe, Y., Ditto 28: 1-11 (1952). Jones, J. W., Jour. Agric. Res.

40 : 110̄-1123 (1930). Nagai, I., Jour. Coll. Agric. Imp. Univ. Tokyo 8: 1-92 (1921). Nagao, S., Advances in Genetics 4 : 181-211 (1951). and Takahashi, M., Jap. Jour. Genet. Supp. 1: 1-27 (1947). Robinson, G. M. and Robinson, R., Biochem. Jour. 25 : 1687-1705 (1931). Robinson, R., Nature $137: 172$ (1935). 